\title{
MASS PRODUCTION OF ENTOMOPATHOGENIC NEMATODES OF LOCAL ISOLATES AS BIOLOGICAL CONTROL AGENTS OF COFFEE BERRY BORER (Hypothenemus hampei Ferr.)
}

\author{
Wagiyana $^{1}$, Didik Sulistyanto ${ }^{1}$, \& Joko Waluyo ${ }^{2}$ \\ ${ }^{1}$ Department of Plant Pests and Diseases, Faculty of Agriculture, University of Jember, Indonesia \\ ${ }^{2}$ Department of Biology, Faculty of Teaching and Education, Universty of Jember, Indonesia \\ Jl. Kalimantan 37, Jember 68121 \\ E-mail:wagiyana@gmail.com
}

\begin{abstract}
Mass production of entomophatogenic nematodes of local isolates as biological control agents of coffee berry borer (Hypothenemus hampei Ferr.). Entomopathogenic Nematodes (EPNs) that serve as biological control agents include Steinernema spp. and Heterorhabditis spp. EPNs Heterorhabditis indicus (Bromo isolate) has a high toxicity against larvae Lepidoptera and Coleoptera and was successfully developed for mass production in Biological Control Laboratory of Jember University. These nematodes will be formulated as solid and liquid biopesticides. This research aimed to find EPNs local isolates from smallholder coffee plantations; to identify local and in vivo and in vitro cultured EPNs isolates; to determine the pathogenicity of EPNs local isolate against coffee berry borrer (CBB) Hypothenemus hampei Ferr. and to formulate entomopathogenic nematodes in vitro culture as a liquid and solid formula. These formula were tested for the patogenicity and viability of entomopathogenic nematodes to the larvae of H.hampei, Tenebrio molitor and Galleria melonella. The results showed that the pathogenecity of EPNs isolate to the larvae of CBB in Silo was 30\% after 24 hours and $90 \%$ after 48 hours of in vivo inoculation. However, the mortality of CBB larvae was only $10 \%$ by liquid spraying on the coffee berry. The viability was $524 \mathrm{IJ}$ (infective juvenile) on liquid formula packed on polyurethane sponge and this was higher than that on solid formula (330 IJ).
\end{abstract}

Key words: CBB, control, EPNs, mass production

\section{INTRODUCTION}

Exploration of entomopathogenic nematodes (EPNs) in smallholder coffee plantations is expected to be able to find EPNs species that have the power to kill important pests in coffee plants, namely coffee berry borer (CBB) Hypothenemus hampei (Ferr.). The types of nodes found will be cultured in vitro by Bedding method, which is then formulated in liquid and solid form. The main problem in the mass production of entomopathogenic nematodes (EPNs) for formulation as pest control biological agents exists in formulation techniques and applications. Shapiro et al. (2012) suggest that in the production of EPNs, media and other additional materials are needed to support their viability. Isolation and mass production of entomopathogenic nematodes (EPNs) for biological control agents of local isolates Heterorhabditis indicus and their symbionic bacteria have been carried out on a variety of corn, soybean, and cabbage crops that produce potential nematodes such as biological control agents for insect pests (Afifah et al., 2013). The indicator of the successful formulation of EPNs is the viability of EPNs in the carrier media during storage and pathogenicity of EPNs to H. hampei (Raya et al., 2015) showed that nematode Heterorhabditis spp. has a high efficacy toward honeycomb moth Galleria melonella indicated by its mortality by $95 \%$ after 3-6 days of inoculation.

This research aimed to find EPNs local isolates from smallholder coffee plantations; identify EPNs local isolates and to breed them in vivo and in vitro; identify the pathogenicity of EPNs local isolates toward coffee berry borrer; formulate the breeds of EPNs cultured in vitro with liquid and solid formula.

The formula to be made in liquid form (in polyurethane sponge) and solid form (flour and granular) is expected to increase the viability and killing power of local EPNs isolate $H$. indicus as a biological control agent toward coffee berry borer and to produce organic coffee.

\section{MATERIALS AND METHODS}

Research Site. The research was conducted for 6 months, from June to November, 2015, at Biological Control Laboratory, Department of Plant Pests and Diseases, Faculty of Agriculture, University of Jember, 
and in the smallholder coffee plantation in Silo area, Jember. This research included exploration and identification of entomopathogenic nematodes in Karangharjo, Sidomulyo, and Pace villages, District of Silo, Jember. Pathogenicity test of entomopathogenic nematodes of local isolate $H$. indicus. Mass culture of in vivo and in vitro EPNs $H$. indicus local isolates. EPNs formulations produced by mass culture in liquid form (in polyurethan sponges) and solid (flour and granules with zeolite and cythosan media).

EPNs Exploration and Isolation in Smallholder Coffee Plantation. EPNs exploration was carried out smallholder coffee plantations in Karangharjo, Sidomulyo and Pace villages by taking soil samples and then baiting EPNs with $G$. melonella larvae. Identification of EPNs resulted from the exploration and isolation was carried out by observing morphological and behavioral similarities with EPNs Bromo isolates $H$. indicus (Prabowo et al., 2019). Visual identification was done by observing the dead G. melonella larvae resulted by baiting, if the larvae showed symptoms of reddish brown color indicating it was attacked by EPNs Heterorhabditis spp. If the larvae was colored caramel brown, it means that the caterpillar was attacked by Steinernema spp. (Afifah et al., 2013).

Nematode isolates obtained (EPNs Silo isolates) were used as further research materials. EPNs was breed in vivo with white traps method in G. melonella caterpillars in the laboratory. The collected nematodes were filtered and then added with Ringer's solution and stored in culture bottles as the next test material.

\section{Pathogenicity Test of Entomopathogenic} Nematodes of Local Isolates Heterorhabditis. The Pathogenicity test of EPNs found after being breed in vivo and tested for its pathogenicity to larvae H. hampei, G. melonella, and Tenebrio molitor, 20 larvae for each, then EPNs suspensions were dropped at concentration of $10^{6}$ infective juvenile (IJ)/100 mL. Testing on $H$. hampei larvae in red cherry was carried out by spraying method. The mortality of the observed larvae was compared with larvae attacked by EPNs Steinernema carpocapsa reported in previous studies. The test was carried out with completely randomized design (CRD). The pathogenicity test of EPNs Silo isolate H.indicus was conducted on all three types of larvae using 6 inoculation treatments, namely the concentrations of EPNs at: $10^{3} ; 10^{4} ; 10^{5} ; 10^{6} ; 10^{7}$ and $10^{0}$ (control) $\mathrm{IJ} / 500$ $\mathrm{mL}$ which each was repeated three times, and observation of larval mortality was carried out after 48 hours of inoculation.
In vitro mass culture of EPNs of isolate Silo $H$. indicus. Mass culture was carried out in vitro with Bedding method (1984) i.e. artificial feeding, consisting of nutrient broth $5 \mathrm{~g}$; yeast extract $14 \mathrm{~g}$; cereal flour $110 \mathrm{~g}$; vegetable oil $180 \mathrm{~mL}$, aquadest $864 \mathrm{~mL}$; and polyurethane sponge $72 \mathrm{~g}$. Bedding media was inoculated with symbionic bacteria as much as $10 \mathrm{~mL}$ isolates and, after 24 hours, was inoculated again with $10^{6} \mathrm{IJ} / 10 \mathrm{~mL}$ of in vivo cultured EPNs that had been sterilized with $10 \%$ hyamine solution, then incubated for 14 days. If it was no contamination, EPNs $H$. indicus would grow, so that it could be harvested in liquid form to be formulated.

Media Composition of EPNs Heterorhabditis spp. Formulation. Experiments on the composition of media for EPNs formulation in solid form used completely randomized design consisting of 6 treatments of media composition: (A) zeolite 50\% + cythosan 50\%; (B) zeolite $75 \%+$ cythosan $25 \%$; C) zeolite $100 \%$; (D) zeolite $25 \%$ + cythosan $75 \%$, (E) cythosan $100 \%$ and (F) liquid formula in sponge as a control. Solid flour-shaped formulation was made by mixing $200 \mathrm{~g}$ carrier media and then inoculated with EPNs $H$. indicus as much as $10^{7} \mathrm{IJ} / 50 \mathrm{~mL}$. The granular solid formulation was made by dripping EPNs suspensions containing $10^{7} \mathrm{IJ} / 50 \mathrm{~mL}$ on trays that were moved or rocked horizontally, so that granules containing EPNs were formed, while the liquid formula was made by adding EPNs suspensions containing $10^{7} \mathrm{IJ} / 50 \mathrm{~mL}$ on polyurethane sponge in size of $15 \times 9 \times 2 \mathrm{~cm}^{3}$. The formula was stored for 3 months, to be tested for EPNs viability and its killing power toward the three types of experimental larvae mentioned earlier.

\section{RESULTS AND DISCUSSION}

EPNs isolates from the $H$. indicus species was found in Karangharjo, Sidomulyo area, and Pace in the Silo Subdistrict. It can be seen from the results of baiting using G. melonella larvae which showed a change in color from white to reddish brown, odorless, and slightly rather stiff. This is in accordance with the results of the study of Afifah et al. (2013) and Susurluk et al. (2013) Entomopathogenic nematodes obtained from Silo have morphological similarities with Bromo isolates of $H$. indicus type, which have slow and regular movements in water. Identification according morphometric $H$. indicus have: Morfometri Entomopathogens nematode of $H$. indicus: spicula length $=(52-62 \mu \mathrm{m})$; IJ length $=$ $621 \mu \mathrm{m}, \mathrm{T}=61 \mu \mathrm{m}(54-66 \mu \mathrm{m}) ; \mathrm{E} 5=82 ; \mathrm{EP}=48(42-$ $40 \mu \mathrm{m}) ; \mathrm{E}=82 \%$; morphometrics of this nematode are 
more than those of other Heterorhabditis, mucron present, male $\mathrm{D} \%=60, \mathrm{SW}=0,94 ; \mathrm{GS}=0,81$, head truncate to slightly rounded, six lips well developed, separated, each with a terminal papilla; amphidial opening small, Stoma wide but shallow, cheilorhabdiuons present, forming a ring; posterior part of stoma covered by esophagus, esophagus witoutmetacorpus; isthmus slender, basal bulb swollen, valve in basal bulbreduced, vulva slight anterior to mid-body $(\mathrm{V} \%=43-48)$. Infective Jouveniles: Third-stage IJ usually with sheath. Sheath with anterior tessellate pattern and longitudinal ridges, IJ cuticle striated with one smooth band marguinated by two ridges in lateral fields. Head with prominent dorsal tooth; mouth and anus closed. Soma appearing as a closed chamber with parallel walls. Esophagus and intestine reduced. Excretory pore posterior to nerve ring. Symbion bacterial cells found in intestine (Susurluk et al., 2013).

Pathogenicity of Entomopathogenic Nematodes Heterorhabditis of Local Isolate. EPNs pathogenicity test results of isolation from Silo coffee plantations (Karangharjo, Sidomulyo, and Pace) on Coffee Berry Borer larvae H. hampei, G. melonella, and T.molitor showed that the mortality caused by EPNs reached 50\% after 24 hours of inoculation (Table 1). This is because EPNs of Siloisolates contain symbionic bacteria which can penetrate directly into the body of the experimental larvae to live in haemolimph by killing insect larvae. The pathognicity of EPNs Silo isolates (Karangharjo, Sidomulyo, and Pace) caused different larval mortality, each reaching $30 \%$ after 24 hours and $90 \%$ after 48 hours of inoculation (Table 2). Intests carried out in the laboratory, ideally mortality could reach $100 \%$ after 48 hours.
The mortality caused is lower than the results of tests conducted by Raya et al. (2015) which reached $95 \%$ of G. melonella larvae. This occurs due to differences in the length of testing that lasts 3 to 6 days.

The results of the study by Khairunisa et al. (2014) reported that the pathogenicity of nematodes Heterorhabditis spp., by the same test method indicated the effectiveness of nematodes against insect pests Oryctes rhinoceros reached $86.7-100 \%$. The killing ability/pathogenicity test of EPNs of Karangharjo, Sidomulyo, and Pace isolates by spraying EPNs isolates on coffee beans showed that the mortality of $H$. hampei larvae in coffee beans was only $3-10 \%$ (Table 3 ).

Which was much lower than the mortality of Phthorimaeao perculella in potato bulbs which reached 95\%. According to Rusniarsyah et al. (2015), the higher mortality in potato tuber moth can occur because the hole made on potato tubers is larger than that by $H$. hampei in coffee beans. Small holes reduce the chance of EPNs to enter coffee beans, so that $H$. hampei larvae are not affordable by EPNs. The entomopathogenic nematode $H$. bacteriophora $\left(\mathrm{LD}_{50}=14.95 \mathrm{IJ} / \mathrm{mL}\right)$ has a higher effectiveness than Steinernema spp. $\left(\mathrm{LD}_{50}=\right.$ $15.22 \mathrm{IJ} / \mathrm{ml}$ ) in controlling soil termite pests Calosotermes spp. (Qodriyah et al., 2015).

Formulation of EPNs Heterorhabditis spp. in solid form; Flour formula was made by mixing $75 \%$ zeolite with $25 \%$ cytosan as much as $200 \mathrm{~g}$, which was added with $10^{7} \mathrm{IJ} / 40 \mathrm{~mL}$ EPNs; whereas granular formulas obtained granules with diameters of 1-1.123 $\mathrm{mm}$ containing nematodes. The liquid formula in polyurethane sponges $\left(12 \times 7 \times 2 \mathrm{~cm}^{3}\right)$ which was given $50 \mathrm{~mL}$ of $10^{7} \mathrm{IJ}$ nematode suspension, then put into a plastic bag clip as in Figure 1. EPNs (Heterorhabditis

Table 1. Mortality of three types of larvae invested by EPNS Heterorhabditis spp. of local isolate

\begin{tabular}{lcccc}
\hline \multirow{2}{*}{ Source of EPNs isolate } & Species of larvae & \multicolumn{3}{c}{ Mortality of larvae (\%) } \\
\cline { 3 - 5 } & H. hampei & 30 & 48 HAI & 72 HAI \\
\hline \multirow{3}{*}{ Karangharjo } & T. molitor & 50 & 90 & 100 \\
& G. melonella & 45 & 60 & 85 \\
\multirow{2}{*}{ Sidomulyo } & H. hampei & 30 & 85 & 95 \\
& T. molitor & 35 & 50 & 100 \\
\multirow{3}{*}{ P a c e } & G. melonella & 30 & 72 & 76 \\
& H. hampei & 25 & 45 & 95 \\
& T. molitor & 23 & 60 & 100 \\
& G. melonella & 20 & 90 & 89 \\
\hline
\end{tabular}

HAI: hours after inoculation 
spp.) has good viability in liquid formulas in the sponge (Table 4).

This is because the large number of pores that can store water films and maintain moisture, so that the nematodes can still survive. Flour and liquid formulas are packed with aluminum foil and plastic which are given the trademark Coleonema as a bioinsecticide with active ingredients $10^{7} \mathrm{IJ}$ Heterorhabditis spp. as shown in Figure 2.
EPNs viability in solid formulas ( $75 \%$ zeolite and $25 \%$ cytosan) reaching $17.8 \times 10^{3} \mathrm{IJ}$ can be stored for 3 months, because cytosan is an additional source of nutrition for EPNs (Table 5), so that it can maintain the viability of stored nematodes (Setyobudi \& Wagiyana, 2008; Shapiro-Illan et al., 2012; Razek et al., 2018). According to Shapiro-Illan et al. (2012), the formulas made require preservation materials, binder and protectant to maintain the killing ability against insects,

Table 2. Pathogenicity of EPNS H. indicus of Silo Isolat of three types of larvae

\begin{tabular}{cccc}
\hline \multirow{2}{*}{ Concentration $+(\mathrm{IJ} / 500 \mathrm{~mL})$} & \multicolumn{3}{c}{ Mortality of experimental larvae $(\%)$} \\
\cline { 2 - 4 } & H. hampei & G. melonella & T. molitor \\
\hline $10^{3}$ & $10 \mathrm{~d}$ & $10 \mathrm{~d}$ & $0 \mathrm{e}$ \\
$10^{4}$ & $30 \mathrm{c}$ & $40 \mathrm{c}$ & $60 \mathrm{bc}$ \\
$10^{5}$ & $70 \mathrm{~b}$ & $70 \mathrm{~b}$ & $80 \mathrm{~b}$ \\
$10^{6}$ & $90 \mathrm{a}$ & $100 \mathrm{a}$ & $100 \mathrm{a}$ \\
$10^{7}$ & $100 \mathrm{a}$ & $100 \mathrm{a}$ & $100 \mathrm{a}$ \\
$10^{0}$ (control) & $0 \mathrm{e}$ & $0 \mathrm{e}$ & $0 \mathrm{e}$ \\
\hline
\end{tabular}

Number in one column followed by the same letter is not different according to DMRT test at significance level $5 \%$.

Table 3. Mortality of Larvae $H$. hampei in red cherry coffee invested by EPNs $H$. indicus of Silo isolate

\begin{tabular}{|c|c|c|c|}
\hline \multirow{2}{*}{ EPNs Type } & \multirow{2}{*}{ Replication } & \multicolumn{2}{|c|}{ Mortality (\%) } \\
\hline & & $3 \mathrm{DAI}$ & $5 \mathrm{DAI}$ \\
\hline \multirow{4}{*}{ Heterorhabditis spp. } & 1 & 0 & 0 \\
\hline & 2 & 10 & 20 \\
\hline & 3 & 5 & 10 \\
\hline & Average & 5.0 & 10.0 \\
\hline \multirow[t]{4}{*}{ Steinernema spp.* } & 1 & 0 & 0 \\
\hline & 2 & 5 & 10 \\
\hline & 3 & 5 & 15 \\
\hline & Average & 3.3 & 8.3 \\
\hline Control & - & 0 & 0 \\
\hline
\end{tabular}

* :as a control, DAI: day after inoculation.

Table 4. Viability of nematode H. indicus of Silo isolate at various formula of bioinsecticide

\begin{tabular}{cccc}
\hline \multirow{2}{*}{ Replication } & \multicolumn{3}{c}{ Total nematode (IJ) } \\
\cline { 2 - 4 } & Liquid in sponge & Flour & Granular \\
\hline 1 & 500 & 330 & 210 \\
2 & 650 & 255 & 326 \\
3 & 238 & 345 & 318 \\
4 & 763 & 248 & 142 \\
5 & 563 & 341 & 235 \\
\hline Average & $542.8 \mathrm{a}$ & $303.8 \mathrm{~b}$ & $246.2 \mathrm{c}$ \\
\hline
\end{tabular}

Average number followed by letter is not different according to DMRT test at significance level of 5\%. 


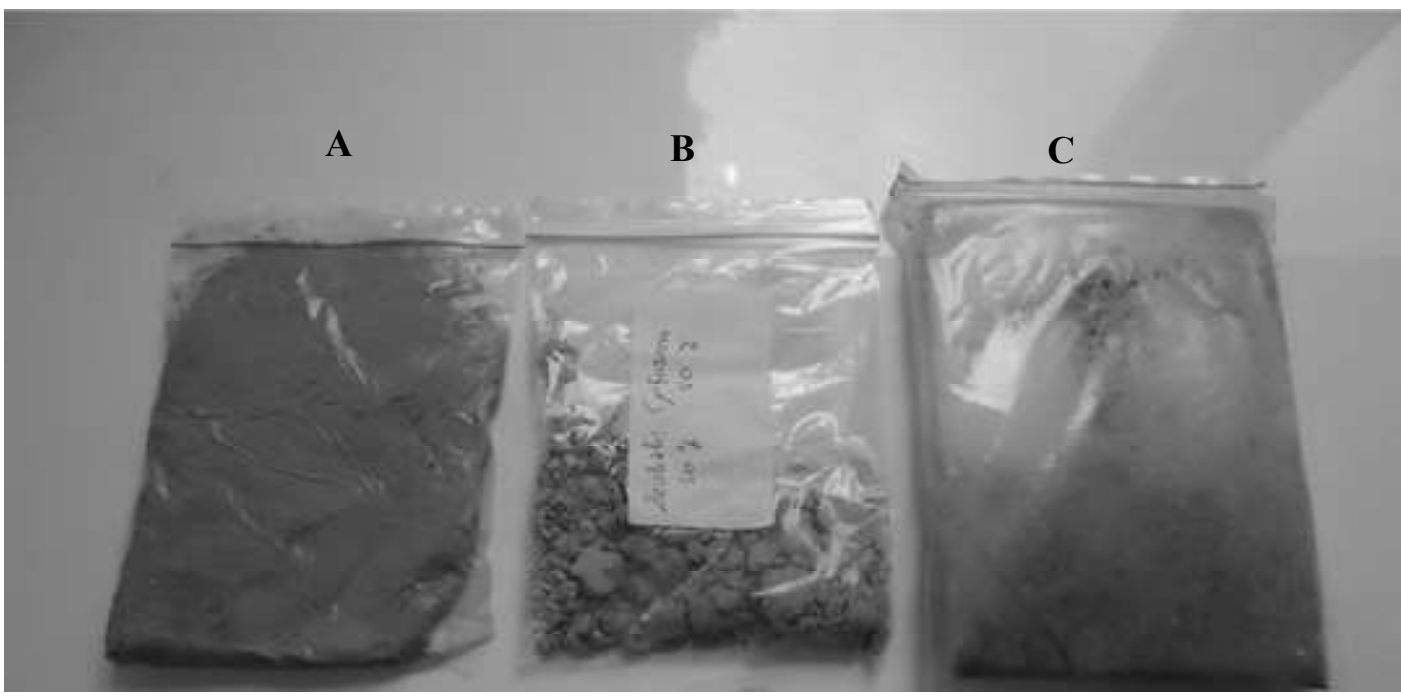

Figure 1. Formula of Entomopathogenic Nematodeson zeolite 75\% and Cythosan 25\%, A. Flour, B. Granular, and C. Liquid in Polyurethane sponge.

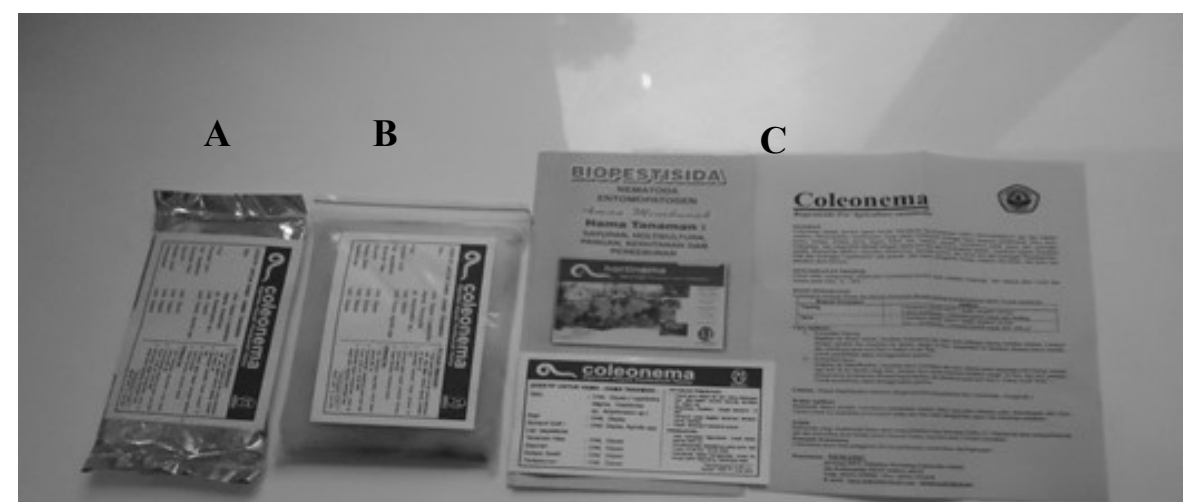

Figure 2. Formula of bio insecticide with active ingredient Entomopathogenic c Nematode $H$. indicus of Silo isolate A. Flour in aluminum foil, B. Liquid formula in Polyurethan sponge, and C. Brochure and technical instructionof bioinsecticide Coleonema application.

Table 5. Viability of EPNs H.indicus of Silo isolate at various compositions of zeolite; cythosan Media

\begin{tabular}{ccccc}
\hline \multirow{2}{*}{$\begin{array}{c}\text { Media composition } \\
\text { zeolite : cythosan }\end{array}$} & 60 & 70 & 80 & 100 \\
\cline { 2 - 5 } $50 \%: 50 \%$ & 1.10 & 1.10 & 0.50 & 0.10 \\
$75 \%: 25 \%$ & 56.6 & 37.8 & 30.4 & 17.8 \\
$25 \%: 75 \%$ & 18.6 & 16.8 & 12.5 & 0.26 \\
$100 \%: 0 \%$ & 0.53 & 0.53 & 0.57 & 0.26 \\
$0 \%: 100 \%$ & 0.26 & 0.50 & 0.10 & 0.03 \\
\hline
\end{tabular}


in line with the results of research by Ali \& Warthon (2015).

In producing and formulating EPNs, additional ingredients are needed to support the killing power and viability of EPNs such as cryoprotectant, while the storage of formulas at low temperatures can be added with trehalose or glycerol. Shapiro-Ilan et al. (2012) states that the formulation of entomopathogenic nematodes produced by mass culture requires additional materials such as cryoprotectant, surfactant, and glycerol to keep the nematode alive in the formulas made.

The solid in liquid formula in polyurethane sponge is the best formula. This is because the material can support the viability of nematodes reaching $542 \mathrm{IJ} / 1 \mathrm{~g} /$ $100 \mathrm{~mL}$, whereas in flour formulas only reaching 303 $\mathrm{IJ} / 1 \mathrm{~g} / 100 \mathrm{~mL}$, and this is in accordance with research by Prabowo (2018) showing that liquid formulas in polyurethane sponge are the most visible in EPNs storage.

\section{CONCLUSION}

The results of the exploration of Entomopathogenic Nematodes (EPNs) in smallholder coffee plantations found $H$. indicus of Silo isolate, which is similar in morphology and behavior with $H$. indicus nematode of Bromo isolate. The killing ability of EPNs resulted from Silo isolates against $H$. hampei larvae reaches $30 \%$ and $90 \%$ after 24 and 48 hours of inoculation. The killing ability of EPNs $H$. indicus on $H$. hampeii larvae in coffee beans only reaches $8-10 \%$. Liquid formulas in polyurethane sponges have high viability of EPNs (542 IJ), flour (303 IJ). The concentrations of EPNs $10^{6}$ and $10^{7} \mathrm{IJ} / 500 \mathrm{~mL}$ are the optimum concentrations to cause mortality of $H$. hampei larvae. EPNs liquid formula (containing $10^{7} \mathrm{IJ} / 50 \mathrm{~mL}$ ) and solid (flour and granular $10^{7} \mathrm{IJ} / 200 \mathrm{~g}$ ) was given the trademark Coleonema.

\section{ACKNOWLEDGMENT}

This research was supported by the University of Jember DIPA for Fiscal Year 2014 and 2015. Contract Number: DIPA 023.04.2.414995/2014. We appreciate Prof. Dr. Ir. Wiwiek Sri Wahyuni, MS who provided corrections and input to this manuscript.

\section{REFERENCES}

Abdel-Razek AS, Hussein M, \& Shehata I. 2018. Isolation and identification of indigenous entomopathogenic nematode (EPN) isolate from egyptian fauna. Arch. Phytopathol. PFL. 51(34): 197-206.

Afifah L, Rahardjo BT, \& Tarno H. 2013. Eksplorasi nematoda entomopatogen pada lahan tanaman jagung, kedele, dan kubis di Malang serta virulensinya terhadap Spodoptera litura Fabricus. J. HPT. 1(2): 1-9.

Ali F \& Wharton DA. 2015. Infective jouveniles of the entomopathogenic nematode, Steinernema feltiae produce cryoprotectants in response to freezing and cold acclimation. J. PLOS ONE. 10(10): $\mathrm{e} 0141810$.

Bedding RA. 1984. Large scale production, storage and transport of the insect parasitic nematodes Neoaplectana spp. and Heterorhabditis spp. Ann. Appl. Biol. 104(1): 117-120.

Khairunisa S, Pinem MI, \& Zahro F. 2014. Uji efektivitas nematoda entomopatogen sebagai pengendali penggerek pucuk kelapa sawit Oryctes rhinoceros L. (Coleoptera: Scarabaeidae) di laboratorium. J. Online Agroteknol. 2(2): 607620.

Qodiriyah, Sulistyanto D, \& Purwatiningsih. 2015. Agens pengendali hayati nematoda entomopatogen Heterorhabditis sp. dan Steinernema sp. sebagai pengendali hama rayap tanah Captotermes sp. dan Macrotermes sp. di Kabupaten Lumajang. J. I. Dasar. 16(1): 43-48.

Raja KR, Hazir C, Gumus A, Asan C, Karagoz M, \& Hazir S. 2015. Efficacy of entomopathogenic nematode Heterorhabditis bacteriophora using different application methods in the presence or absence of a natural enemies. Turk. J. Agric. For. 39(2): 277-285.

Rusniarsyah L, RaufA, Supramana, \& Samsudin. 2015. Patogenisitas dan keefektifan nematoda entomopatogen Heterorhabditis sp. terhadap penggerek umbi kentang Phthorimaea operculella (Zeller) (Lepidoptera: Gelechiidae). J.Silvikultur Tropika. 6(1): 66-70.

Shapiro-Illan D, Han R, \& Dolinksi C. 2012. Entomopathogenic nematode production and application technology. J. Nematol. 44(2): 206217.

Shapiro-Illan D, Rojas MG, Morales-Ramos JA, \& Tedders WL. 2012. Optimization of a host diet for in vivo production of entomopathogenic nematodes. J. Nematol. 44(3): 264-273. 
Setyobudi B \& Wagiyana. 2008. Pemanfaatan zeolit sebagai bahan pembuatan biopestisida berbahan aktif nematoda Steinernema spp. berbentuk granuler. J. Zeolit Ind. 7(2): 108-112.
Susurluk IA, Kongu Y, \& Ulu TC. 2013. Quality control of in vitro produced Heterorhabditis bacteriophora (Rhabditida: Heterorhabditidae) strains isolated from Turkey. Turk. Entomol. Derg-Tu. 37(3): 283-291. 